Journal of Environmental Sciences (JES)

Institute of Environmental Studies and Research, Ain Shams University

Abo Bakr, Reham et al.

\title{
REDUCTION OF TRIHALOMETHANE PRECURSORS USING ENHANCED COAGULATION
}

\author{
Reham A. Abo Bakr ${ }^{(1)}$; Mostafa M. Khali( ${ }^{(2)}$ and Nabil A. Abdullah ${ }^{(3)}$ \\ 1) Egyptian Holding Company for Water and Wastewater 2) Faculty of \\ Science, Ain Shams University 3) Aluminum Sulfate Company of Egypt
}

\begin{abstract}
Jar tests were conducted to simulate the conventional processes of water treatment. Enhanced coagulation used the traditional alum that is already applied in water treatment in Egypt, with a comparison with ferric chloride and mixture of alum and ferric chloride, the strategy of enhanced treatment adopted mainly organic matter and THMs beside turbidity, so the doses of coagulant were increased to achieve better removal of THMs which have an health issue. Conventional treatment processes including addition of aluminum sulphate or ferric chloride to the raw water followed by coagulation, sedimentation and rapid sand filtration are important step in water purification. They reduced the organic matter to about $42 \%$ and THMs to 37 using the baseline dose $(25 \mathrm{mg} / \mathrm{l})$. The enhanced coagulation process by increasing the dose of alum reduced the total organic carbon and THMs to 57 $\%$ and $54 \%$ respectively. Using of ferric chloride at a baseline dose reduced TOC and THMs by $40 \%$ and $36 \%$ respectively, while enhanced coagulation by increasing the dose of ferric chloride (at a dose of $35 \mathrm{mg} / \mathrm{l}$ ) raised up the removal of TOC and THMs to $47 \%$ and $44 \%$ respectively. The dual coagulant of alum and ferric chloride achieved $47 \%$ removal of TOC and $36 \%$ for THMs at a dosage of $25 \mathrm{mg} / \mathrm{l}$, while the enhanced coagulation by increasing the dose of duel coagulant of alum and ferric chloride $(35 \mathrm{mg} / \mathrm{l})$ raising up the removal of TOC to $61 \%$ and THMs to $50 \%$. The advantageous of the dual coagulant is higher reduction of residual aluminum and THMs, this attributed to the enhancement of flocculation which create activated adsorption sites of flocs surfaces.
\end{abstract}

Key words: Water, Water treatment, Coagulation, TOC, THMs. 
Journal of Environmental Sciences (JES)

Institute of Environmental Studies and Research, Ain Shams University

Abo Bakr, Reham et al.

\section{INTRODUCTION}

Natural organic matter (NOM) is defined as a complex matrix of organic materials present in all natural water. The hydrophilic fractions of NOM are composed mostly of aliphatic carbon and nitrogenous compounds, as carboxylic acids, carbohydrates and proteins. Hydrophobic NOM primarily consists of humic and fulvic acids (Matilainen et al. 2010). Particular increase of interest in the composition of humic substances in water is noted since the publication of research regarding the generation of trihalomethanes (THMs) during the chlorination of water. THMs precursors are mainly humic acids, metabolites of aquatic organisms, mono-, di- and tri-carboxylic acids, and aromatic carboxylic acids (Poleneni and Inniss, 2015 and Dojlido 2002).

Four derivatives of methane belong to THMs group: chloroform $\mathrm{CHCl}_{3}$, bromoform $\mathrm{CHBr} 3$, bromodichloromethane $\mathrm{CHCl} 2 \mathrm{Br}$, dibromochloromethane $\mathrm{CHClBr} 2$. They also have a certain binding potential for multivalent metal ions and hydrophobic organic materials such as pesticides, therefore, the content of dissolved organic matter in drinking water ought to be kept low (Her et al., 2003; Zhang et al., 2020).

A number of regulations regarding the potential effects of DBPs have been developed by the United States Environmental Agency (US EPA, 1998). The disinfection/ disinfection by-product (D/DBP) Rule has set maximum permissible concentration of total THMs in drinking water to be $80 \mathrm{mg} / \mathrm{l}$. The rule mandates utilities that using chlorine for disinfection, to remove total organic carbon as a measure for reducing DBP precursors. 
Analyses of water collected in different water treatment plants and also in pool water confirm the possibility of THMs presence in water subjected to chlorination (Abdullah et al. 2003; Kim 2009; Chang et al. 2010; Pardakhti et al. 2011 and Lee et al. 2009).

The conventional chemical coagulation processes with aluminum sulphate and ferric chloride followed by sedimentation and rapid sand filtration are important step in water purification. Most of chemical coagulation processes were essentially designed for turbidity and particulate removal. However, these processes are not efficient for the removal of many occurring organic micro pollutants (Margot et al., 2013; Stackelberg et al., 2007; Ternes et al., 2002; Troeger et al., 2018).

Granular activated carbon (GAC) filtration is one of the advanced technologies for organic carbon that may increase the rate of removal (Margot et al., 2013; Stackelberg et al., 2007), but this is not always achieved (Troeger et al., 2018 and complete extraction is often not done (McCleaf et al., 2017; Troeger et al., 2018).

Activated carbon removal efficiency for organic materials decreases with time (Kennedy et al., 2015; McCleaf et al., 2017) and this is adversely affected by the dissolved organic materials (Lavonen et al., 2015 and McCleaf et al., 2017).

The contents of some organic material in surface water are affected to great extent by upstream sources, such as wastewater treatment plant, and 
Journal of Environmental Sciences (JES)

Institute of Environmental Studies and Research, Ain Shams University

Abo Bakr, Reham et al.

other human activities (Gago-Ferrero et al., 2017; Loos et al., 2013; Soerengard et al., 2019).

The development of awareness towards the presence of organic pollutants in surface waters, lead to review the water management titled "Drinking Water Directive (98/83/EC) and the organic substances of importance in the Water Framework Directive was included (Fuerhacker, 2009).

Certain NOM fractions were preferentially removed like humic (hydrophobic) and higher molecular weight NOM are more effectively reduced (Owen et al., 1993). It was found that a preferential reduction in ultraviolet absorbance (UVA) compared to dissolved organic carbon (DOC), indicated preferential removal of aromatic (Humic) NOM (Imai et al., 2003; Reckhow and Singer, 1990).

Organic matter content in water is reduced by coagulation (ŚwiderskaBróż et al. 2008; Matilainen et al. 2010; Alexander et al. 2012; Jeong et al. 2014). Removal depends on physico-chemical composition of water, $\mathrm{pH}$ value, type and dosage of coagulants. The most often used aluminium coagulants are aluminium sulphate $\mathrm{Al}_{2}\left(\mathrm{SO}_{4}\right)_{3}$ and aluminium chloride $\mathrm{AlCl}_{3}$.

Aluminum irons can remove NOM according to two mechanisms: (1) adsorption on aluminum hydroxide or iron hydroxide flocs and (2) formation of insoluble complexes such as aluminum or iron humates or fulvates (Jacangelo et al., 1995; Randtke, 1993). The first mechanism is more dominant at higher coagulant dosages and higher $\mathrm{pH}$ conditions, whereas the 
Journal of Environmental Sciences (JES)

Institute of Environmental Studies and Research, Ain Shams University

Abo Bakr, Reham et al.

second mechanism is relatively more dominant at lower $\mathrm{pH}$ conditions (Krasner, and Amy, 1995).

Over 90 and $80 \%$ reduction is obtained by coagulation for turbidity and color respectively (Dąbrowska and Rosińska 2013). Research on treatment of water with different compositions confirms the effectiveness of the coagulation in the removal of organic matter (Hussain et al. 2013; Wang et al. 2013).

The concept of enhanced coagulation is used for controlling the precursors of DBPs, where effective coagulation dosages are used for reduction of DOC. Enhanced coagulation was selected as a measure because it was effective for the reduction of DOC and could be executed at water plants treating the surface waters using the existing processes (Owen et al., 1993).

To meet the drinking water standards limits, in conventional water treatment, mixture of aluminum and iron salts was conducted to lower residual aluminum in finished water to an acceptable content (less than 0.2 mg/l) (Li and Mitch , 2018).

This study aims to investigate acceptable approach to enhance coagulation for TOC (DBD precursors), turbidity and aluminum minimization using aluminum and iron based coagulants in drinking water treatment, single and dual dosing with aluminum sulphate and ferric chloride coagulants. Once the condition for optimized coagulation has been determined by Jar tests, TOC was evaluated under baseline coagulation conditions and optimized 
Journal of Environmental Sciences (JES)

Institute of Environmental Studies and Research, Ain Shams University

Abo Bakr, Reham et al.

coagulation. In addition, the study aimed to compare the efficiency of aluminum sulfate, ferric chloride and mixture of the two coagulants for the removal of turbidity and organic substances from water samples collected from River Nile with reference to residual aluminum. Minimizing of operating cost is indirect objective should be achieved.

\section{MATERIALS AND METHODS}

Study area: Surface water samples were collected from the intake of Shubra Al-Khaymah water treatment plant on Ismailia canal (branch of the River Nile). This plant is located in north Cairo. The water was collected in November 2018, Different levels of TOC were recorded in each table (Table 1, Table 2 and Table 3 ) according to different doses of each coagulant.

Sampling Procedure: Water samples were collected in winter of 2018/2019 where high concentrations of organic matter were recorded. Water samples were collected in stopper polyethylene plastic bottles and amber bottles for TOC and THMs. All samples were stored in an ice box with preservation for each parameter and delivered immediately to the laboratory for analyses.

Materials: Coagulants tested were liquid aluminum sulfate $\mathrm{Al}_{2}\left(\mathrm{SO}_{4}\right)_{3} . \mathrm{nH} 2 \mathrm{O} \quad 8 \% \quad \mathrm{Al}_{2} \mathrm{O}_{3}$ (commercial grade), produced by Egyptian aluminum sulfate Co. of Egypt (ASCE), Ferric chloride, 29.6\% $\mathrm{Fe}_{2} \mathrm{O}_{3}$ (commercial grade, India), and mixture of the two salts (50/50). For each raw 
water sample, TOC was assessed before and after treatment under baseline coagulation conditions using the three different coagulants with different doses.

Procedures: Physical and chemical examinations were carried out according to Standard Methods for Examination of Water and Wastewater $23^{\text {rd }}$ eddition (APHA, 2017).

Table (1): The analyzed parameters, method of analysis and instruments

\begin{tabular}{|c|c|c|c|c|c|}
\hline No. & Parameter & $\begin{array}{l}\text { Unit } \\
\text { Used }\end{array}$ & Used method. & Reference & Instrument \\
\hline 1 & Turbidity & NTU & $\begin{array}{c}2130 \text { B. } \\
\text { Nephelometric } \\
\text { Method }\end{array}$ & $\begin{array}{l}\text { APHA, } \\
2017\end{array}$ & $\begin{array}{c}\text { HACH } 2100 \mathrm{~N} \\
\text { Turbidmeter }\end{array}$ \\
\hline 2 & $\mathrm{PH}$ & - & $\begin{array}{c}4500 . \mathrm{H}, \mathrm{B} \\
\text { Electrometric } \\
\text { method }\end{array}$ & $\begin{array}{l}\text { APHA, } \\
2017\end{array}$ & $\begin{array}{c}\text { HACH } \\
\text { sension3 } \\
\text { PH Meter }\end{array}$ \\
\hline 3 & $\mathrm{Al}, \mathrm{Fe}$ & $\mathrm{mg} / \mathrm{l}$ & EPA (200.7) & $\begin{array}{l}\text { Maxfield } \\
\text { and } \\
\text { Mindak, } \\
1985\end{array}$ & $\begin{array}{c}\text { ICP-OES } \\
\text { Optima8300 }\end{array}$ \\
\hline 4 & $\begin{array}{l}\text { Total organic } \\
\text { carbon (TOC) }\end{array}$ & $\mathrm{mg} / \mathrm{l}$ & $\begin{array}{c}5310 \text { Total } \\
\text { Organic Carbon } \\
\text { (TOC) }\end{array}$ & $\begin{array}{l}\text { APHA, } \\
2017\end{array}$ & Siever5310C \\
\hline 5 & $\begin{array}{l}\text { Trihalomethan } \\
\left(\mathrm{THM}_{\mathrm{s}}\right)\end{array}$ & $\mu \mathrm{g} / \mathrm{L}$ & EPA (551.1) & $\begin{array}{c}\text { Hautman } \\
\text { and } \\
\text { Munch, } \\
1997\end{array}$ & $\begin{array}{l}\text { GC-ECD } \\
\text { Thermo- } \\
\text { Trace1300 }\end{array}$ \\
\hline 6 & residual chlorine & $\mathrm{mg} / \mathrm{l}$ & $\begin{array}{c}\text { 4500-CLG DPD } \\
\text { Colorimetric } \\
\text { Method }\end{array}$ & $\begin{array}{l}\text { APHA, } \\
2017\end{array}$ & $\begin{array}{c}\text { Lovibond } \\
\text { Chlorine } \\
\text { MD100 } \\
\end{array}$ \\
\hline
\end{tabular}

All samples were brought to room temperature $\left(25^{\circ} \mathrm{C}\right)$ prior to jar testing.

one liter samples were performed using standard jar test procedure. Two 
Journal of Environmental Sciences (JES)

Institute of Environmental Studies and Research, Ain Shams University

Abo Bakr, Reham et al.

kinds of coagulants dosing approaches, including single dosing aluminum sulphate and ferric chloride and dual dosing. Initial rapid mixing was conducted at $200 \mathrm{rpm}$ for $1 \mathrm{~min}$. followed by slow mixing at $40 \mathrm{rpm}$ for 20 min. Then the flocks were allowed to settle for $20 \mathrm{~min}$., the turbidity of the supernatant was measured by turbidity meter, $\mathrm{PH}$ was measured by $\mathrm{PH}$ meter, Total organic carbon (TOC) was measured by TOC analyzer Trihalomethan (THMs) was measured by gas chromatography with electron capture detector, Iron and residual aluminum was measured by ICP.

This research was conducted using jar testing to simulate drinking water treatment processes in laboratory. This instrument is a widely accepted and used method for understanding the effects of treatment processes changes at lab scale (AWWA, 1992).

Jar tests that simulated the plants conditions ( $\mathrm{pH}$ of coagulation, coagulant type and dose) is termed "baseline coagulation" were done using alum as coagulant. The aim of "baseline" jar tests was to compare the jar test results with the full-scale plant data, and serve as a level for comparison with the optimized coagulation conditions.

Enhancing coagulation was performed using a series of bench-scale jar tests. With different coagulant dosages (the baseline dosage used by the plant). TOC concentrations were measured with UV- Persulfate TOC analyzer, model Phoenix 8000, USA after filtration of the samples through $0.45 \mu \mathrm{m}$ membrane. 
Journal of Environmental Sciences (JES)

Institute of Environmental Studies and Research, Ain Shams University

Abo Bakr, Reham et al.

\section{RESULTS AND DISCUSSIONS}

Physical and chemical examinations of water samples collected from the intake of Shubra Al-Khaymah WTP during winter 2018/2019. The prechlorine dose was $5.5 \mathrm{mg} / \mathrm{l}$ according to break point procedure.

Table (2) shows that the raw water contains a relatively high turbidity, $\mathrm{pH}$ and organic matter, and upon using chlorine, slight reduction of $\mathrm{pH}$ was reported. Figure (1) shows the influence of alum doses on TOC and THMs removal. Using alum reduced the turbidity, $\mathrm{pH}$ and organic matter (TOC). The percentage of removal of organic matter (TOC) and Trihalomethane $\left(\mathrm{THM}_{\mathrm{S}}\right)$ are increasing by increasing alum doses as shown in Figure 1. The percentage of removal of organic matter (TOC) and by-products $\left(\mathrm{THM}_{\mathrm{S}}\right)$ is more than $55 \%$ complying with that reported by (Ndabigengesere, and Narasiah, 1998).by increasing alum doses $\mathrm{pH}$ was reduced this increases the precipitation of aluminum in water and we see decreasing residual aluminum in water as shown in Figure2. Trihalomethane $\left(\mathrm{THM}_{\mathrm{S}}\right)$ is reduced with increasing alum doses as shown in Figure 3. 
Table (2): Effect of alum dose on reduction of turbidity, TOC, THMs and residual aluminum

\begin{tabular}{|c|c|c|c|c|c|c|c|c|}
\hline $\begin{array}{c}\text { Dose of } \\
\text { liquid alum. } \\
\text { Sulphate } \\
(\mathrm{mg} / \mathrm{l})\end{array}$ & $\begin{array}{c}\text { Turbidity } \\
\text { (NTU) }\end{array}$ & pH & $\begin{array}{r}\text { TOC } \\
(\mathrm{mg} / \mathrm{l})\end{array}$ & $\begin{array}{c}\text { TOC } \\
\text { remova } \\
\mathbf{I}(\%)\end{array}$ & $\begin{array}{l}\text { THMs } \\
(\mu \mathrm{g} / \mathrm{L})\end{array}$ & $\begin{array}{l}\text { THM } \\
\text { remov } \\
\text { al }(\%)\end{array}$ & $\begin{array}{l}\text { R. Al } \\
(\mathbf{m g} / \mathbf{l})\end{array}$ & $\begin{array}{l}\text { R. Cl } \\
(\mathbf{m g} / \mathbf{l})\end{array}$ \\
\hline Raw Water & 8.5 & 8.31 & 6.4 & $0 \%$ & N/A & N/A & 0.05 & N/A \\
\hline $\begin{array}{c}\text { Raw } \\
\text { Chlorinated } \\
\end{array}$ & 7.9 & 8.09 & 5.91 & $8 \%$ & 88.3 & $0 \%$ & 0.04 & 2.85 \\
\hline 10 & 1.4 & 7.5 & 3.93 & $35 \%$ & 66.18 & $25 \%$ & 0.25 & 2.4 \\
\hline 15 & 1.3 & 7.44 & 3.88 & $39 \%$ & 63.65 & $28 \%$ & 0.21 & 2.4 \\
\hline 20 & 1.20 & 7.4 & 3.76 & $41 \%$ & 59.02 & $33 \%$ & 0.18 & 2.4 \\
\hline 25 Baseline & 1 & 7.36 & 3.53 & $45 \%$ & 55.69 & $37 \%$ & 0.16 & 2.4 \\
\hline 30 & 0.95 & 7.31 & 3.22 & $50 \%$ & 50.3 & $43 \%$ & 0.14 & 2.4 \\
\hline 35 & 0.84 & 7.23 & 2.75 & $57 \%$ & 40.83 & $54 \%$ & 0.12 & 2.4 \\
\hline
\end{tabular}




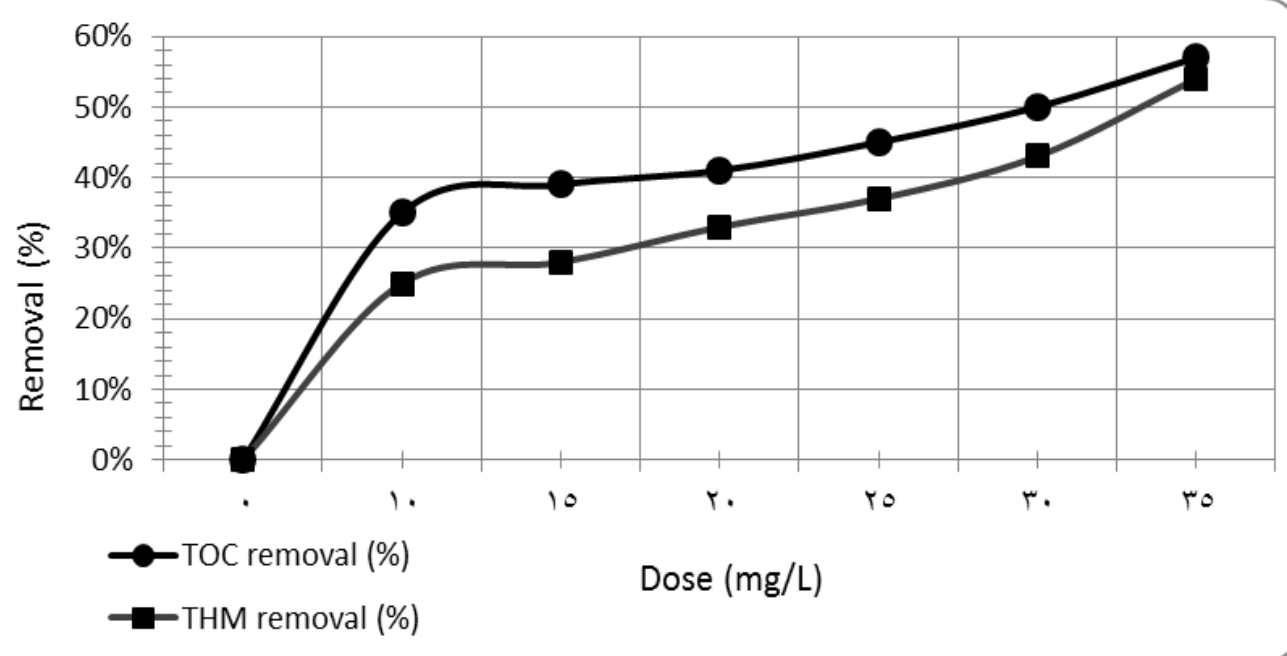

Figure (1): Removal percentage of TOC and THMs using aluminum sulphate

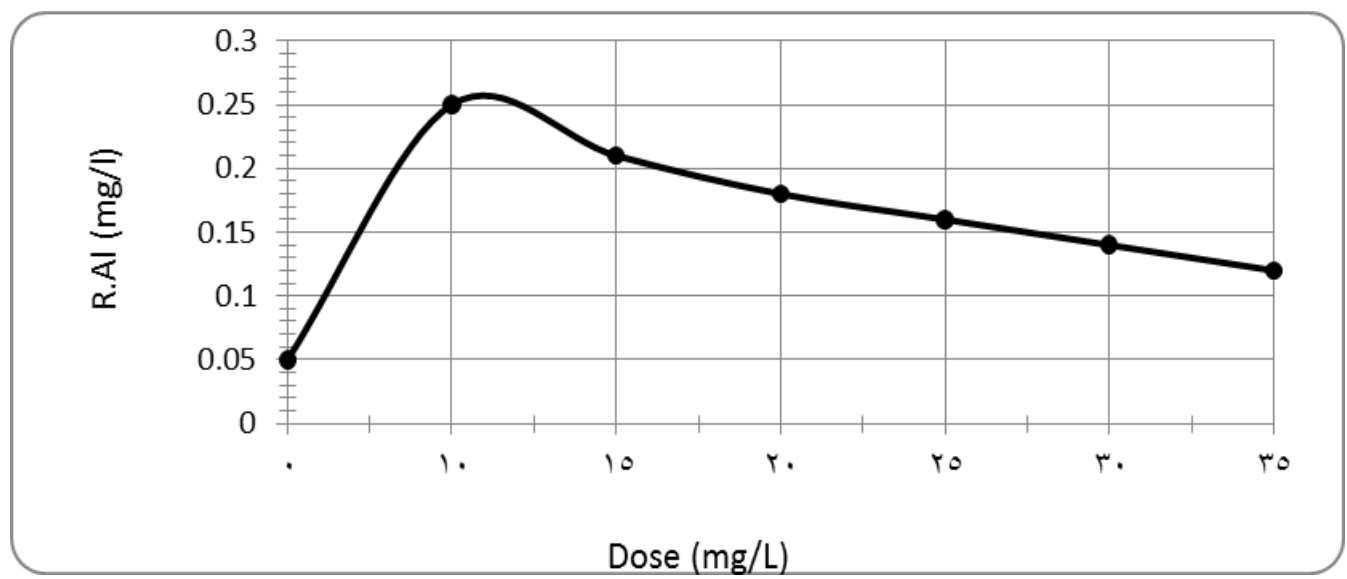

Figure (2): Relation between doses of aluminum sulphate and residual aluminum 


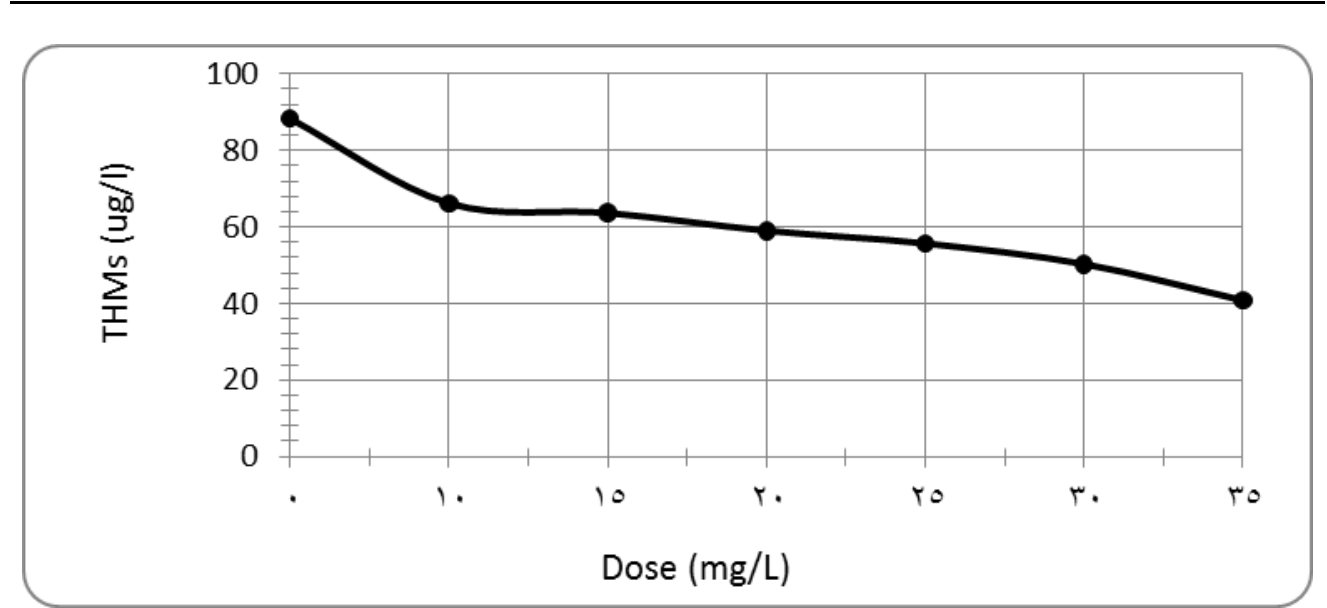

Figure (3): Relation between doses of Aluminum Sulphate and Trihalomethanes

Upon using of ferric chloride, turbidity, $\mathrm{pH}$, organic matter (TOC) and byproducts $\left(\mathrm{THM}_{\mathrm{S}}\right)$ are reduced with increasing the dose until $35 \mathrm{mg} / 1$, the percentage of removal of organic matter (TOC) is more than $47 \%$ and removal of byproducts $\left(\mathrm{THM}_{\mathrm{S}}\right)$ is about $44 \%$ agreeing with that reported by. (Pikkarainen, et al., 2004). There is no baseline for $\mathrm{FeCl}_{3}$ because it is not currently used, and we depend in our experiment on the already used coagulant (alum), it was supposed to be as alum $(25 \mathrm{mg} / \mathrm{l})$. increasing the dosage of ferric chloride, resulted in corresponding residual iron in water in small dosages, but it decrease as the dosage increase as a result of enhancement of settleability due to growing up of flocs and become more compact and heavy causing low residual iron in water (Fig. 5). THMs were reduced with the higher dosages (Fig. 6). 
Table (3): Effect of ferric chloride dose on reduction of turbidity, TOC, THMs

\begin{tabular}{|c|c|c|c|c|c|c|c|c|}
\hline $\begin{array}{l}\text { Dose of ferric } \\
\text { chloride } \\
\text { (mg/l) }\end{array}$ & $\begin{array}{l}\text { Turbidity } \\
\text { (NTU) }\end{array}$ & pH & $\begin{array}{l}\text { TOC } \\
(\mathrm{mg} / \mathrm{l})\end{array}$ & $\begin{array}{c}\text { TOC } \\
\text { removal } \\
(\%)\end{array}$ & $\begin{array}{l}\text { THMs } \\
(\mu \mathrm{g} / \mathrm{L})\end{array}$ & $\begin{array}{c}\text { THM } \\
\text { removal } \\
(\%)\end{array}$ & $\begin{array}{c}\mathrm{Fe} \\
(\mathrm{mg} / \mathrm{l})\end{array}$ & $\begin{array}{l}\text { R. Cl } \\
(\mathrm{mg} / \mathrm{l})\end{array}$ \\
\hline Raw Water & 8.5 & 8.31 & 6.4 & $0 \%$ & N/A & N/A & 0.2 & N/A \\
\hline $\begin{array}{c}\text { Raw } \\
\text { Chlorinated } \\
\end{array}$ & 7.9 & 8.09 & 5.91 & $8 \%$ & 88.3 & $0 \%$ & 0.18 & 2.85 \\
\hline 10 & 1.5 & 7.2 & 4.60 & $28 \%$ & 76.82 & $18 \%$ & 0.5 & 2.5 \\
\hline 15 & 1.4 & 7.1 & 4.13 & $35 \%$ & 65.69 & $26 \%$ & 0.42 & 2.5 \\
\hline 20 & 1.30 & 7 & 3.98 & $38 \%$ & 61 & $31 \%$ & 0.36 & 2.5 \\
\hline 25 Baseline & 1.19 & 6.95 & 3.80 & $41 \%$ & 58.3 & $34 \%$ & 0.30 & 2.5 \\
\hline 30 & 1 & 6.88 & 3.60 & $44 \%$ & 53.36 & $39 \%$ & 0.27 & 2.5 \\
\hline 35 & 0.9 & 6.75 & 3.45 & $47 \%$ & 49.62 & $44 \%$ & 0.23 & 2.5 \\
\hline 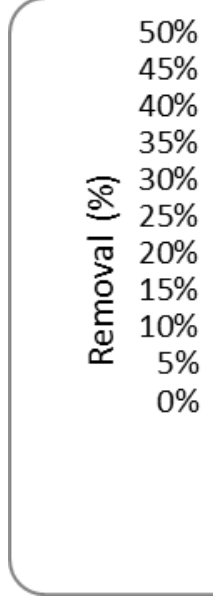 & • & & e $(\mathrm{mg}$ & r. & - & $\begin{array}{l}\text { TOC re } \\
\text { THM re }\end{array}$ & $\begin{array}{l}\text { val (\%) } \\
\text { oval (\%) }\end{array}$ & مo \\
\hline
\end{tabular}

Figure (4): Removal percentage of TOC and THMs using Ferric Chloride 
Table (4) Effect of mixed solution of Aluminum Sulphate and Ferric Chloride on reduction of turbidity, TOC, THMs and residual aluminum

\begin{tabular}{|c|c|c|c|c|c|c|c|c|c|}
\hline Dose & $\begin{array}{c}\text { Turbidity } \\
\text { (NTU) }\end{array}$ & $\mathbf{p H}$ & $\begin{array}{c}\text { TOC } \\
(\mathrm{mg} / \mathrm{l})\end{array}$ & $\begin{array}{c}\text { TOC } \\
\text { removal } \\
(\%)\end{array}$ & $\begin{array}{l}\text { THMs } \\
(\mu \mathrm{g} / \mathrm{L})\end{array}$ & $\begin{array}{c}\text { THM } \\
\text { removal } \\
(\%)\end{array}$ & $\begin{array}{r}\text { R. Al } \\
(\mathbf{m g} / \mathbf{l})\end{array}$ & $\begin{array}{c}\mathbf{F e} \\
(\mathbf{m g} / \mathbf{l})\end{array}$ & $\begin{array}{r}\text { R. Cl } \\
(\mathrm{mg} / \mathrm{l})\end{array}$ \\
\hline $\begin{array}{c}\text { Raw } \\
\text { Water }\end{array}$ & 8.5 & 8.31 & 6.4 & $0 \%$ & N/A & N/A & 0.05 & 0.2 & N/A \\
\hline $\begin{array}{c}\text { Raw } \\
\text { chlorinated }\end{array}$ & 7.9 & 8.09 & 5.91 & $8 \%$ & 88.3 & $0 \%$ & 0.04 & 0.18 & 2.85 \\
\hline $10 \mathrm{ppm}$ & 1.2 & 7.4 & 3.88 & $39 \%$ & 62.55 & $29 \%$ & 0.18 & 0.25 & 2.6 \\
\hline $15 \mathrm{ppm}$ & 1.15 & 7.35 & 3.78 & $41 \%$ & 60.31 & $32 \%$ & 0.16 & 0.23 & 2.6 \\
\hline $20 \mathrm{ppm}$ & 1.10 & 7.3 & 3.67 & $43 \%$ & 56.2 & $36 \%$ & 0.13 & 0.18 & 2.6 \\
\hline $\begin{array}{c}25 \text { ppm } \\
\text { Baseline }\end{array}$ & 0.92 & 7.2 & 3.42 & $47 \%$ & 52.43 & $41 \%$ & 0.11 & 0.15 & 2.6 \\
\hline 30 ppm & 0.85 & 7.15 & 2.9 & $55 \%$ & 45.89 & $48 \%$ & 0.09 & 0.12 & 2.6 \\
\hline 35 ppm & 0.79 & 7.12 & 2.2 & $65 \%$ & 35.13 & $60 \%$ & 0.07 & 0.10 & 2.6 \\
\hline
\end{tabular}

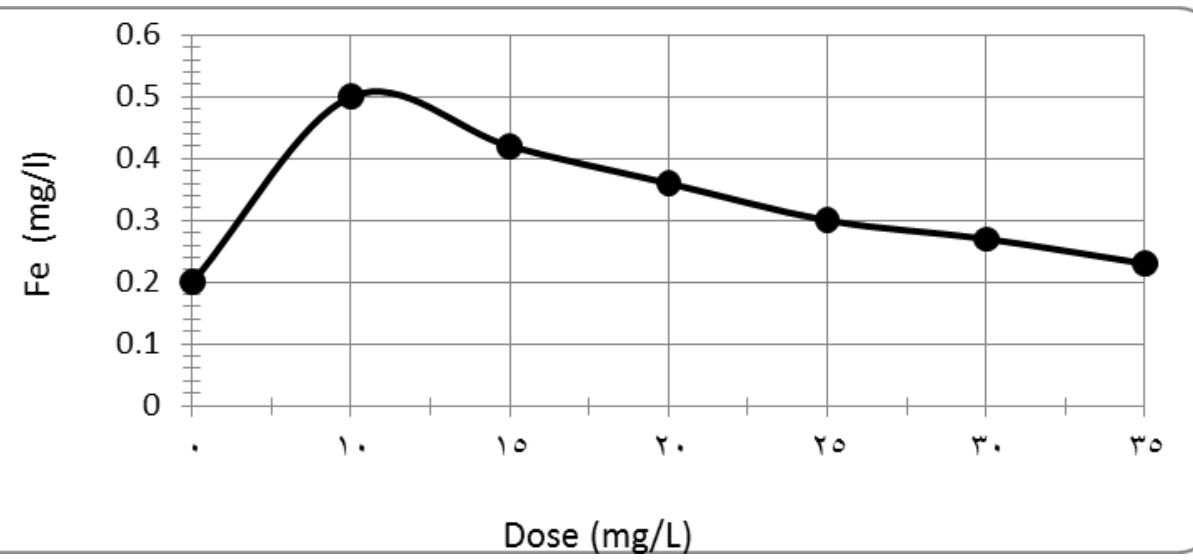

Figure (5): Relation between doses of Ferric Chloride and Fe 


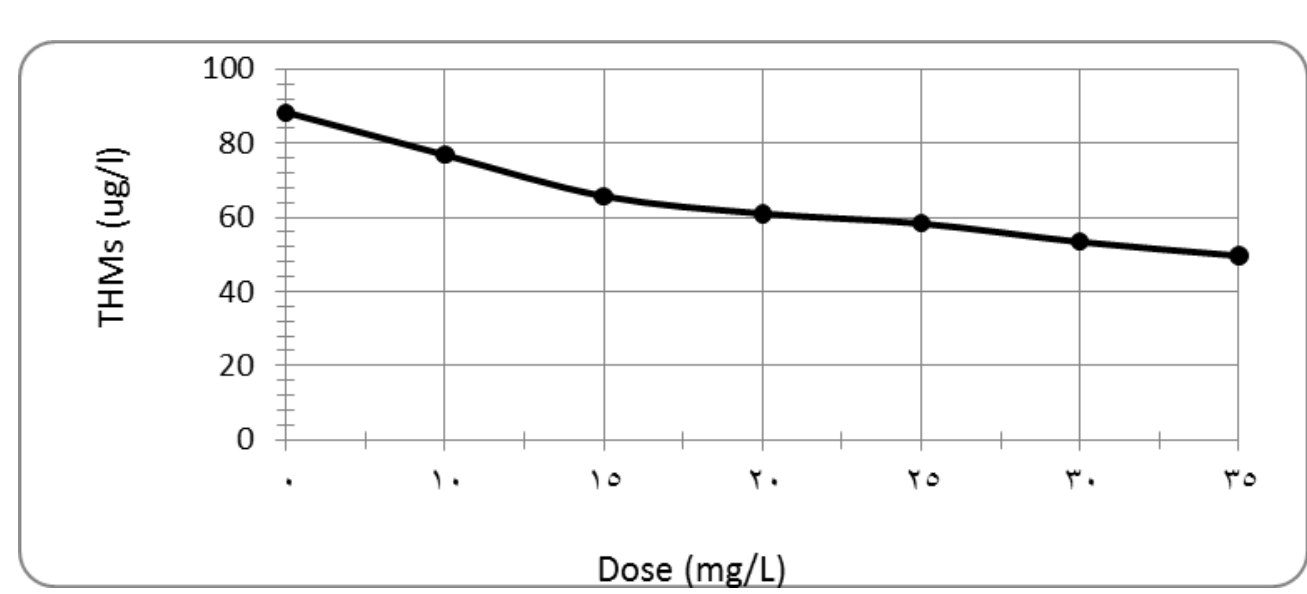

Figure (6): Relation between doses of Ferric Chloride and Trihalomethane

Using mixture of Aluminum Sulphate and Ferric Chloride at a dose of 35 $\mathrm{mg} / \mathrm{l}$, the percentage of removing organic matter (TOC) was about $65 \%$ and removal of THMs was about $60 \%$ as shown in( Figure7). Agreeing with that reported by (Crozes, et al., 1995). The TOC and THMs removal in the effluents with all three coagulants was higher than the baseline control 25 $\mathrm{mg} / \mathrm{l}$ of aluminum sulphate which is the common dose applied in the water treatment plant of shoubra alkhema. Increasing the dose of coagulants resulted in decreasing of $\mathrm{pH}$, which enhance precipitation of aluminum and iron hydroxide, consequently, low residual and iron were detected (Fig. 8). Precipitation of Iron increase in water by increasing of increasing dual mixture doses due to presence of Aluminum Sulphate in dual mixture which increase of activity of Precipitation of Iron in water by forming very large and heavy flocs which is increasing of Precipitation of Iron in water as shown in 
Journal of Environmental Sciences (JES)

Institute of Environmental Studies and Research, Ain Shams University

Abo Bakr, Reham et al.

(Figure9). Trihalomethane $\left(\mathrm{THM}_{\mathrm{S}}\right)$ is reduced with increasing dual mixture doses as shown in (Figure 10).

The organic matter as TOC and the THMs reduction in the plant effluent with the three coagulants were higher than the baseline dosage. At normal dosages in the plants which depends essentially on turbidity removal, the removal of TOC and THMs were they reduce the organic matter to about $45 \%$ and THMs to 37 using the baseline dose $(25 \mathrm{mg} / \mathrm{l})$. The enhanced coagulation process using alum reduced the total organic carbon and THMs to $57 \%$ and $54 \%$ respectively by aluminum sulfate. Using of ferric chloride at a baseline dose reduced TOC and THMs by $41 \%$ and $34 \%$ respectively, while enhanced coagulation (at a dose of $35 \mathrm{mg} / \mathrm{l}$ ) raised up the removal of TOC and THMs to $47 \%$ and $44 \%$ respectively. The dual coagulant of alum and ferric chloride achieved $61 \%$ removal of TOC and 50\%. At baseline dose, residual aluminum was $0.16 \mathrm{mg} / \mathrm{l}$ using alum and $0.11 \mathrm{mg} / \mathrm{l}$ using dual mixture (Fig. 2, 8), but at enhanced doses residual aluminum dropped to 0.06 $\mathrm{mg} / \mathrm{l}$ for dual coagulant and $0.12 \mathrm{mg} / \mathrm{l}$ for alum. Residual iron was reduced to $0.1 \mathrm{mg} / \mathrm{l}$ at $35 \mathrm{mg} / \mathrm{l}$ as $\mathrm{FeCl}_{3}$, while it was $0.15 \mathrm{mg} / \mathrm{l}$ at baseline dose (Fig. 9). 
Abo Bakr, Reham et al.

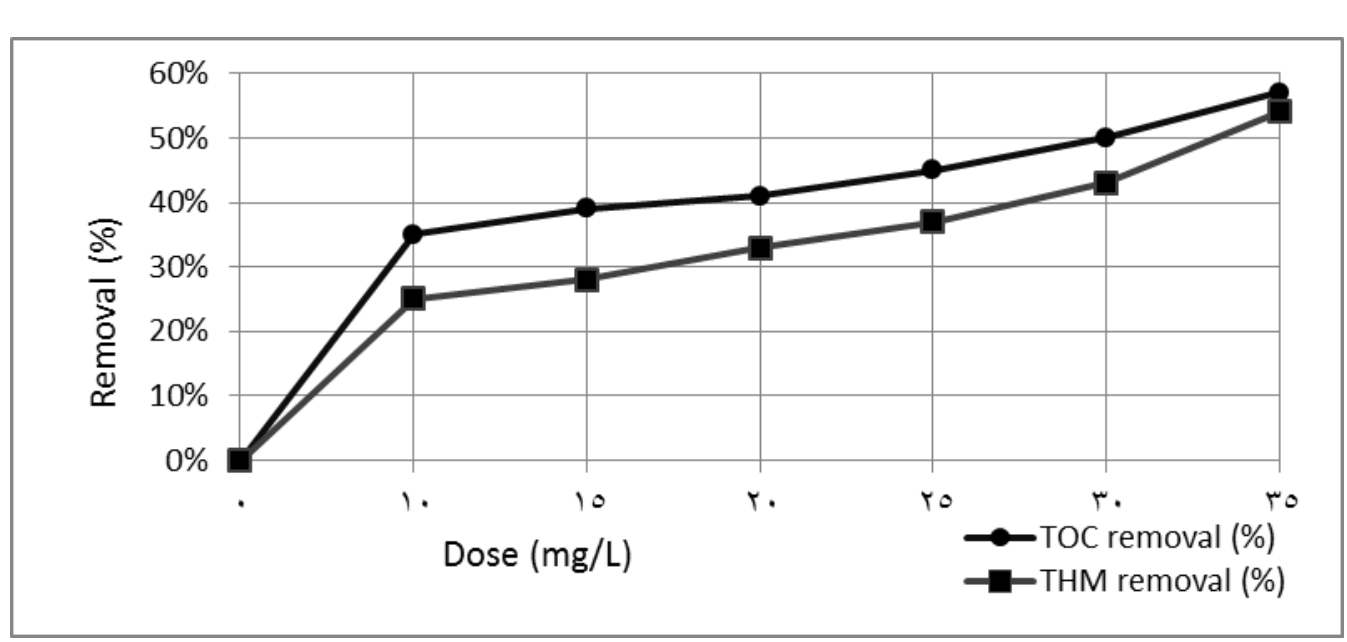

Figure (7): Removal percentage of TOC and THMs by coagulant mix

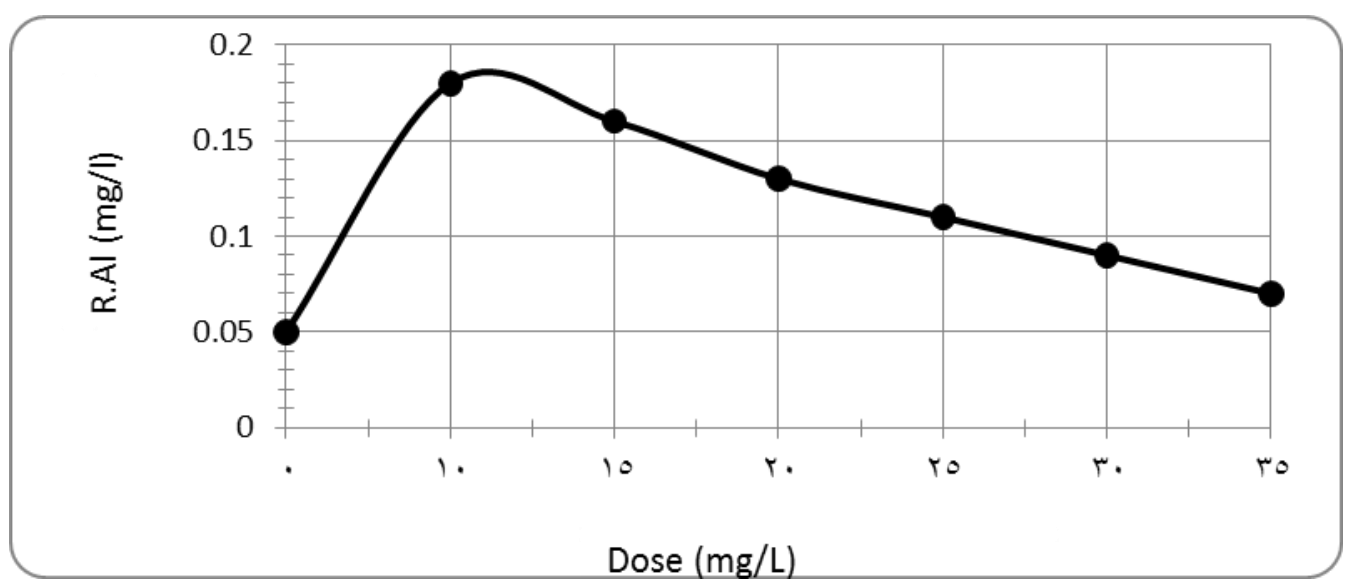

Figure (8): Relation between doses of Mix of Aluminum Sulphate Ferric

Chloride and residual Aluminum 
Journal of Environmental Sciences (JES)

Institute of Environmental Studies and Research, Ain Shams University

Abo Bakr, Reham et al.

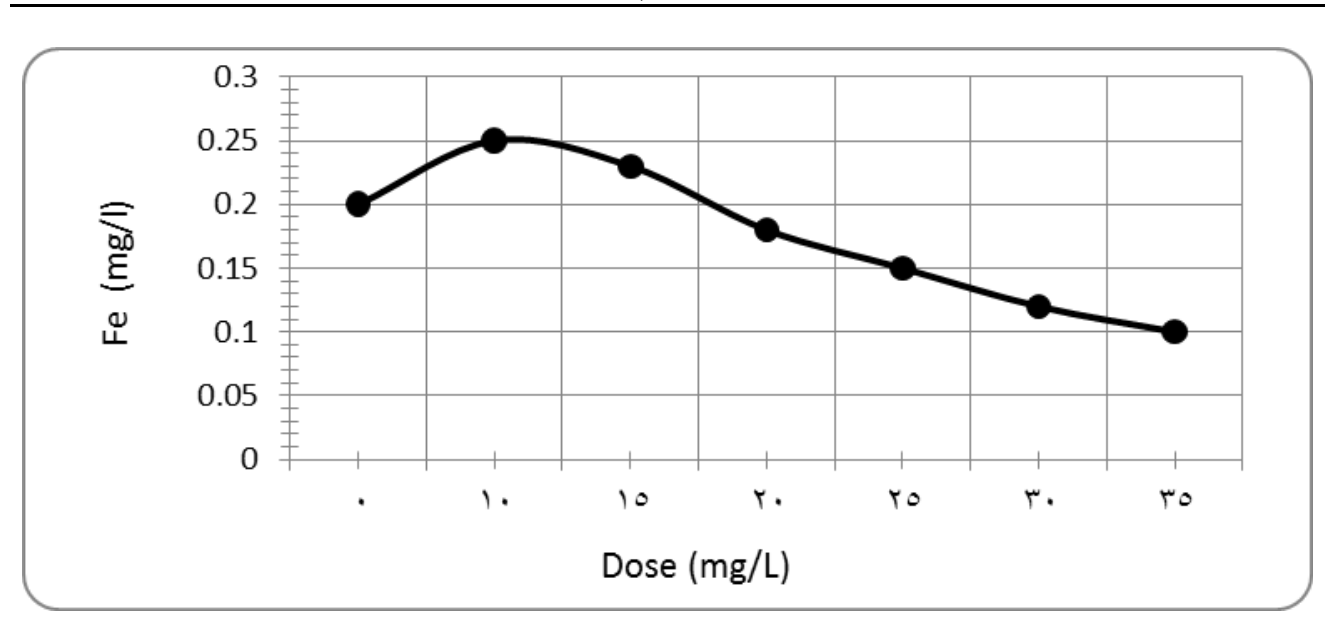

Figure (9): Relation between doses of Mix of Aluminum Sulphate Ferric Chloride and $\mathrm{Fe}$

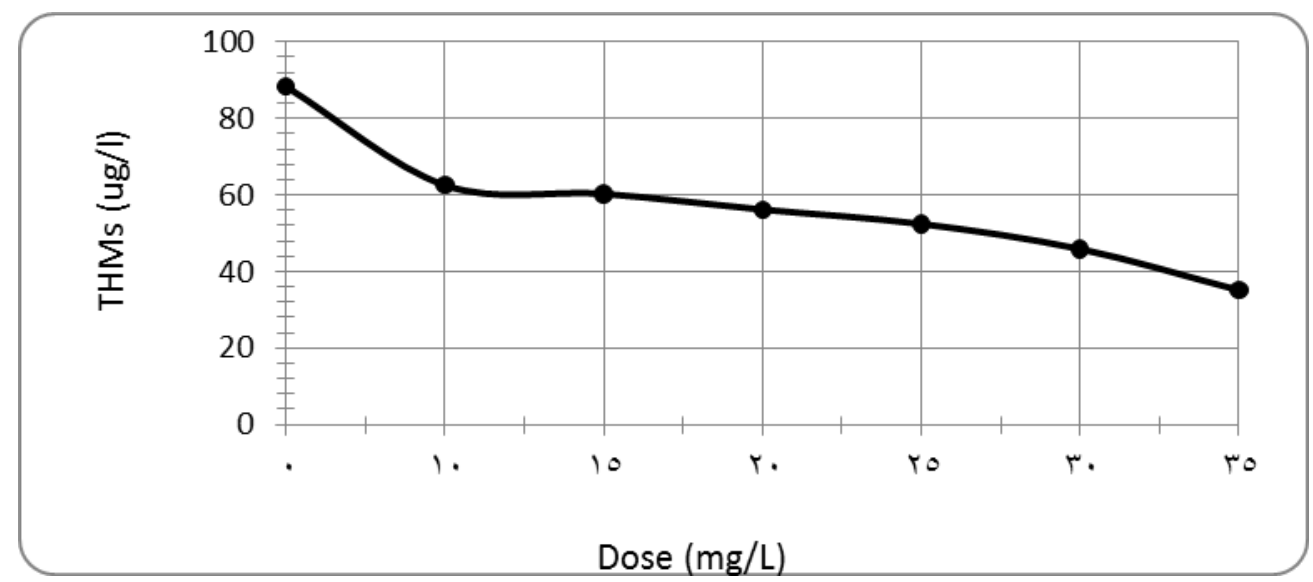

Figure (10): Relation between doses of Mix of Aluminum Sulphate Ferric

Chloride and Trihalomethane 
Journal of Environmental Sciences (JES)

Institute of Environmental Studies and Research, Ain Shams University

Abo Bakr, Reham et al.

\section{CONCLUSION}

This study was performed as enhanced coagulation that will provide additional removal of organic matter (TOC) and the corresponding THMs that have a health issue. The protocol for enhancement adopted an effective dosage for removal of organic matter as a precursor for THMs, and utilization of the active adsorption sites on surface of flocs generated during coagulation and flocculation. The baseline for comparison taken $25 \mathrm{mg} / \mathrm{l}$ which is the average dose applied in the plant of Shubra Al-Khaymah WTP. The percentage removal of TOC for alum, ferric chloride and dual coagulant were improved by $12 \%, 6 \%$ and $14 \%$ respectively. The corresponding improvements of THMs for the coagulants were 17\%, $10 \%$ and $14 \%$ respectively. The percentage additional reduction of residual aluminum for alum and the dual coagulant were $25 \%$ and $54.5 \%$ respectively. Residual iron improved by $33.3 \%$. These results were carried out on the settled water so after filtration they will be better. THMs concentration for baseline $52.43 \mu \mathrm{g}$ and after enhancement it became $35.13 \mu \mathrm{g}$ lower than the max permissible limit which is $100 \mu \mathrm{g}$. residual aluminum after improvement become 0.12 $\mathrm{mg} / \mathrm{l}$ for alum and $0.07 \mathrm{mg} / \mathrm{l}$ for dual coagulant, while the max limit is 0.2 $\mathrm{mg} / \mathrm{l}$. Residual iron was $0.1 \mathrm{mg} / \mathrm{l}$, and the max limit is $0.3 \mathrm{mg} / \mathrm{l}$. 


\section{REFERENCES}

Abdullah Md.P.; Yew C.H. and Salleh Bin Ramli M. (2003): Formation, modeling and validation of trihalomethanes (THM) in Malaysian drinking water: a case study in the districts of Tampin, Negeri Sembilan and Sabak Bernam, Selangor, Malaysia. Water Research, 37, 4637-4644.

Alexander J.T.; Hai F.I. and Al-aboud T.M. (2012): Chemical coagulationbased processes for trace organic contaminant removal: Current state and future potential. Journal of Environmental Management, $111,195-207$.

APHA (1998): Standard methods for the examination of water and wastewater. 20th ed. American Public Health Association, Washington, DC.

APHA, AWWA and WEF. Standard Methods for the Examination of Water and Wastewater, $20^{\text {th }}$ ed.; APHA,

AWWA and WEF: Washington, DC, USA, 1998.

Baird, R. \& Bridgewater, L. (2017): Standard methods for the examination of water and wastewater. $23^{\text {rd }}$ edition. Washington, D.C.: American Public Health Association.

Chang H.H; Tung H.H.; Chao C.C. and Wang G.S. (2010): Occurrence of haloacetic acids (HAAs) and trihalomethanes (THMs) in drinking water of Taiwan. Environmental Monitoring and Assessment 162, 237-250.

Crozes, G.; White, P. and Marshall, M. (1995): Enhanced coagulation: its effect on NOM removal and chemical costs. Journal American Water Works Association, 87(1), pp.78-89.

Dąbrowska L. and Rosińska A. (2013): Removal of PCBs and heavy metal ions from surface water by coagulation. Rocznik Ochrona Środowiska, 15, 1228-1242. 
Directive, W. F. (2019/06/20): http://ec.europa.eu/environment/water/waterdangersub/ pri_substances.htm.

Dojlido J. (red) (2002): Uboczne produkty dezynfekcji wody. Seria Wodociągi i Kanalizacja nr 9. Wyd. ZG PZIiTŚ, Warszawa. Gumińska J. 2012. Analysis of the possibility to assess the prehydrolyzed coagulants based on their basicity. Przemysł Chemiczny, 91 (12), 2351-2354.

Fuerhacker, M. (2009): EU water framework directive and Stockholm convention. Environmental Science and Pollution Research, 16(1), 92-97.

Gago-Ferrero, P.; Gros, M.; Ahrens, L. and Wiberg, K., (2017): Impact of onsite, small and large scale wastewater treatment facilities on levels and fate of pharmaceuticals, personal care products, artificial sweeteners, pesticides, and perfluoroalkyl substances in recipient waters. Sci. Total Environ. 601, 1289-1297. https://doi.org/10.1016/j. scitotenv.2017.05.258.

Hautman, D. P. and Munch, D. J. (1997): Development of US EPA method 551.1. Journal of chromatographic science, 35(5), 221-231.

Her N.; Amy G.; McKnight D. Sohn J. and Yoon Y. (2003): Characterization of DOM as a function of molecular weight by fluorescence EEM and HPLC - SEC using UVA, DOC and fluorescence detection. Wat. Res., 4295-4303.

https://doi.org/10.1016/j.scitotenv.2007.01.095.

Hussain S.; Van Leeuwen J.; Chow Ch.; Beecham S.; Kamruzzaman M.; Wang D.; Drikas M. and Aryal R. (2013): Removal of organic contaminants from river and reservoir waters by three different aluminum-based metal salts: Coagulation adsorption and kinetics studies. Chemical Engineering Journal, 225, 394-405. 
Imai A.; Matsushige K. and Nagai T. (2003): Trihalomethane formation potential of dissolved organic matter in shallow eutrophic lake. Wat. Res., 4284-4294

Jacangelo, J. G.; DeMarco, J.; Owen, D. M. and Randtke, S. J. (1995): Selected processes for removing NOM: an overview, Jour. AWWA. 87, 64-77

Jeong S.; Sathasivan A.; Kastl G.; Shim W.G. and Vigneswaran S. (2014): Experimental investigation and modeling of dissolved organic carbon removal by coagulation from seawater. Chemosphere, 95, 310-316.

Kennedy, A.M.; Reinert, A.M.; Knappe, D.R.U.; Ferrer, I. and Summers, R.S. (2015): Full- and pilot-scale GAC adsorption of organicmicropollutants. WaterRes.68,238-248. https://doi.org/10.1016/j.watres.2014.10.010.

Kim J. (2009): Fate of THMs and HAAs in low TOC surface water. Environmental Research, 109, 158-165.

Krasner, S. W. and Amy, G. L. (1995): Jar -test evaluation on enhanced coagulation Jour. AWWA. 87 (10), $93-107$.

Lavonen, E.E.; Kothawala, D.N.; Tranvik, L.J.; Gonsior, M.; SchmittKopplin, P. and Kohler, S.J. (2015): Tracking changes in the optical properties and molecular composition of dissolved organic matter during drinking water production. Water Res. 85, 286-294.

Lee J.; Ha K-T. and Zoh K-D. (2009): Characteristics of trihalomethane (THM) production and associated health risk assessment in swimming pool waters treated with different disinfection methods. Science of the Total Environment, 407, 1990-1997. 
Li, X. F., and Mitch, W. A. (2018): Drinking water disinfection byproducts (DBPs) and human health effects: multidisciplinary challenges and opportunities. loads, source apportionment, and risk estimation of organic micro-pollutants from hospital and municipal wastewater in recipient catchments. Chemosphere 234, 931-941.

Loos, R.; Carvalho, R.; Antonio, D.C.; Cornero, S.; Locoro, G.; Tavazzi, S. and Gawlik, B.M. (2013): EU-wide monitoring survey on emerging polar organic contaminants in wastewater.

Margot, J.; Kienle, C.; Magnet, A.; Weil, M.; Rossi, L.; deAlencastro, L.F. and Barry, D.A. (2013): Treatment of micropollutants in municipal wastewater: ozone or powdered activated carbon? Sci. Total Environ. 461-462, 480-498. https://doi.org/10.1016/j. scitotenv.2013.05.034.

Matilainen A.; Vepsäläinen M. and Sillanpää M. (2010): Natural organic matter removal by coagulation during water treatment: A review. Advances in Colloid and Interface Science, 159, 189v197.

Maxfield, R. and Mindak, B. (1985): EPA Method Study 27, Method 200.7: Trace Metals by ICP. US Environmental Protection Agency, Office of Research and Development, Environmental Monitoring and Support Laboratory.

McArdell, C.S. (2016): Swiss strategies and results from advancedwastewatertreatmenthttp://www.esamur.com/public/fi le/McArdellSpainNov2016finalcopy.pdf (20181030).

McCleaf, P.; Englund, S.; Ostlund, A.; Lindegren, K.; Wiberg, K. and Ahrens, L. (2017): Removal efficiency of multiple poly- and perfluoroalkyl substances (PFASs) in drinking water using granular activated carbon (GAC) and anion exchange (AE) column tests.Water Res. 120, 77-87. https://doi.org/10.1016/j.watres.2017.04.057 
Ndabigengesere, A. and Narasiah, K.S. (1998): Quality of water treated by coagulation using Moringa oleifera seeds. Water research, 32(3), pp.781-791.

Pardakhti A.R.; Bidhendi G.R.N.; Torabian A.; Karbassi A. and Yunesian M. (2011): Comparative cancer risk assessment of THMs in drinking water from well water sources and surface water sources. Environmental Monitoring and Assessment, 179, 499-507.

Pikkarainen, A.T.; Judd, S.J.; Jokela, J. and Gillberg, L. (2004): Precoagulation for microfiltration of an upland surface water. Water Research, 38(2), pp.455-465

Poleneni, S.R.; Inniss, E.C. Small water distribution system disinfection byproduct control: Water quality management using storage systems. Int. J. Geotech. Constr. Mater. Environ. (Geomate) 2015, 9-17, 1365-1369.[CrossRef]

Sörengård, M.; Campos-Pereira, H.; Ullberg,M.; Lai, F.Y.; Golovko, O. and Ahrens, L. (2019): Mass

Stackelberg, P.E.; Gibs, J.; Furlong, E.T.; Meyer, M.T.; Zaugg, S.D. and Lippincott, R.L. (2007): Efficiency of conventional drinkingwater-treatment processes in removal of pharmaceuticals and other organic compounds. Sci. Total Environ. 377 (2-3), 255272.

Świderska-Bróż M.; Rak M.; Mołczan M. and Biłyk A. (2008): Effect of the basicity of aluminium coagulants and the $\mathrm{pH}$ of the water on the removal of organic pollutants. Ochrona Srodowiska, 30 (4), 2933.

Ternes, T.A.; Meisenheimer, M.; McDowell, D.; Sacher, F.; Brauch, H.J.; Gulde, B.H. and Seibert, N.Z. (2002): Removal of pharmaceuticals during drinking water treatment. Environ Sci Technol 36 (17), 3855-3863. https://doi.org/10.1021/es015757k. 
Tröger, R.; Klockner, P.; Ahrens, L. and Wiberg, K. (2018): Micropollutants in drinking water from source to tap - method development and application of a multiresidue screening method. Sci. Total Environ. 627, 1404-1432. https://doi.org/10.1016/j. scitotenv.2018.01.277.

Wang D.; Zhao Y.; Xie J.; Chow Ch.W.K. and Van Leeuwen J. (2013): Characterizing DOM and removal by enhanced coagulation: A survey with typical Chinese source waters. Separation and $\mathrm{Pu}-$ rification Technology, 110, 188-195.

Zhang, D.; Wang, F.; Duan, Y.; Chen, S.; Zhang, A. and Chu, W. (2020): Removal of trihalomethanes and haloacetamides from drinking water during tea brewing: Removal mechanism and kinetic analysis. Water Research, 116148. 


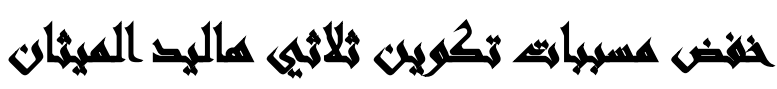

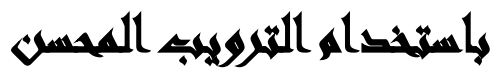

\author{
ريهام عادل على ابو بكر (')- مصطفى محمد حسن خليل(؟)- نبيل أحمد عبد الله محمد(r)

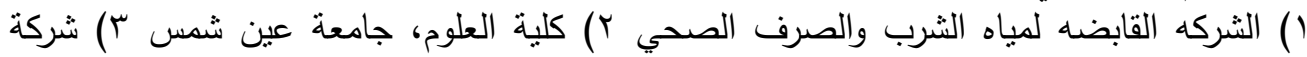

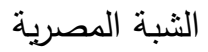

\section{(الم:}

في هذ الدراسة تم استخدام تجربة الكؤوس لمحاكاة المعالجة التقليدية التي تتم في محطات مياه

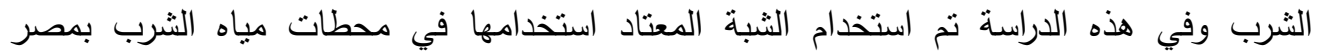

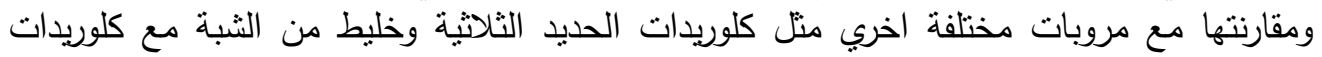

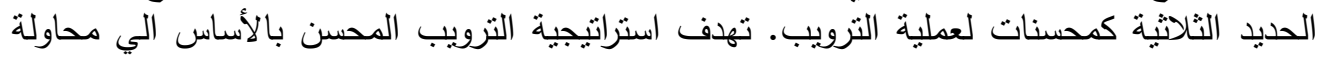

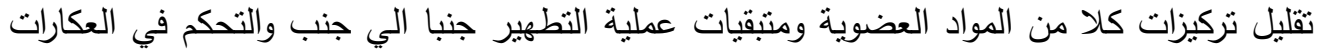

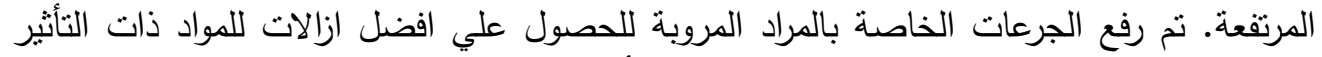

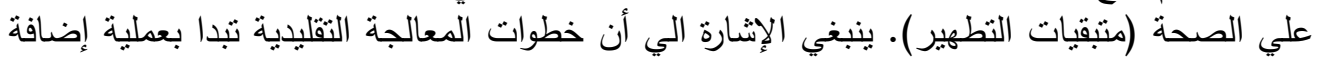

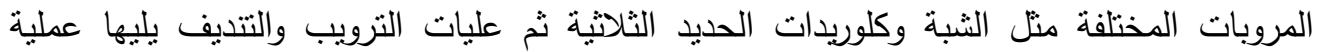

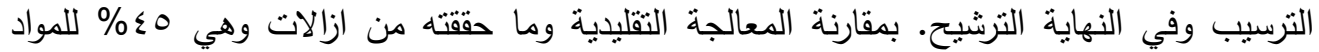

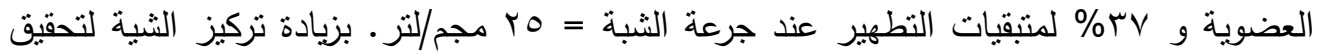

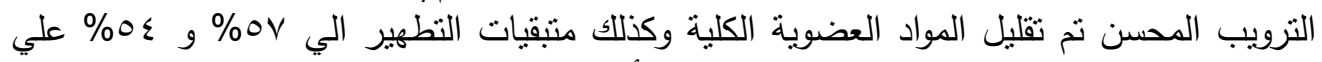

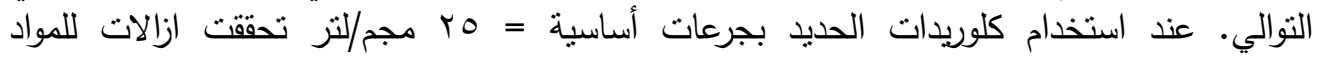

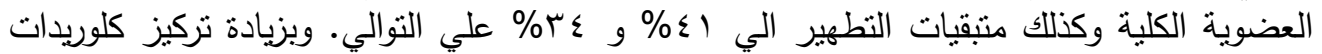

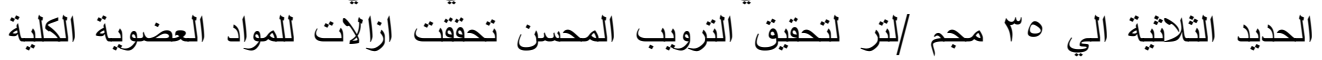

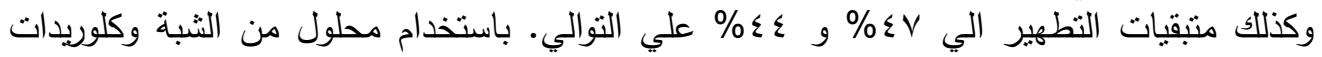

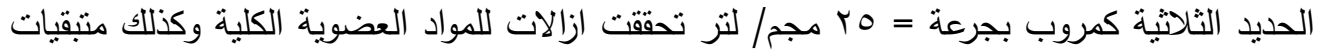

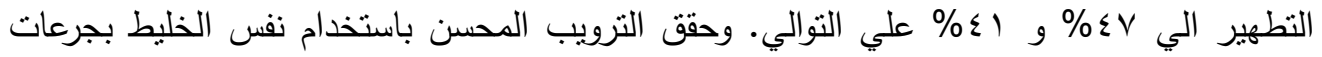

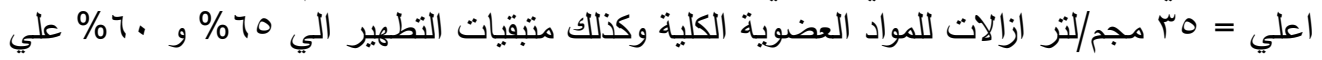

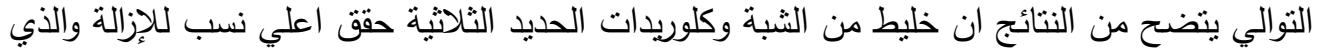

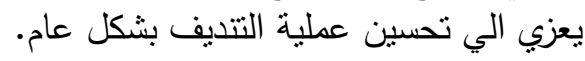

